\title{
Students' Mathematical Thinking in Column Calculation and Algorithms
}

\author{
Puri Pramudiani ${ }^{1}$, Tatang Herman ${ }^{2}$ \\ ${ }^{1}$ PGSD, FKIP Universitas Muhammadiyah Prof. DR. HAMKA, Jl. Tanah Merdeka Kp. Rambutan Jakarta Timur \\ ${ }^{2}$ Program Studi Pendidikan Matematika, FPMIPA, Universitas Pendidikan Indonesia, Jl. Dr. Setiabudhi, Bandung, Jawa Barat \\ puri.pramudiani@uhamka.ac.id
}

\begin{abstract}
This study aims to investigate primary school students' mathematical thinking in column calculation and algorithms. The method used in this research is qualitative descriptive. The participants of this research were twelve Indonesian primary school students at grade 3 and 4 in Ciparay, Bandung, West Java. They worked to solve calculation and algorithm questions developed from TAL TEAM book Freudenthal Institute, Utrecht University, The Netherlands that were classified based on the strategies used. After analyzing their written works, interviews were organized to acquire further information about their mathematical thinking. The study found that students' strategies in dealing with calculation algorithm consist of three strategies. The first strategy is the splitting strategy from units to tens column and then the interim results are combined. The second strategy is the splitting strategy used from tens to unit column and the interim results are added vertically digit-by-digit. The third strategy is the transition from splitting strategy from units to tens column consists primarily of using abbreviated column calculation for the interim results in each column. In addition, several students made common mistakes due to misconception about algorithm and arithmetical problems. Implication of this research for teaching and learning calculation and algorithms were described elaborately.
\end{abstract}

Keywords: students' mathematical thinking, calculation, algorithm, primary school

\begin{abstract}
Abstrak
Penelitian ini bertujuan untuk menyelidiki pemikiran matematis siswa sekolah dasar dalam perhitungan nilai tempat dan algoritma. Metode penelitian yang digunakan dalam penelitian ini adalah deskriptif kualitatif. Subjek penelitian ini sebanyak 12 siswa kelas 3 dan 4 di Ciparay Bandung Jawa Barat. Mereka memecahkan soal perhitungan dan algoritma yang dikembangkan dari buku yang disusun oleh TAL TEAM di Freudenthal Institute, Utrecht University, The Netherlands dan diklasifikasikan berdasarkan strategi yang digunakan. Setelah menganalisis jawaban tertulis mereka, wawancara dilakukan untuk memperoleh informasi lebih dalam tentang pemikiran matematis mereka. Dari hasil penelitian ditemukan bahwa strategi siswa dalam mengerjakan algoritma penjumlahan terdiri dari tiga jenis strategi. Strategi pertama adalah menggunakan strategi pemisahan dari kolom satuan ke kolom puluhan dan kemudian hasil sementara digabungkan. Strategi kedua adalah strategi pemisahan yang digunakan dari kolom puluhan ke kolom satuan dan hasil sementara ditambahkan secara vertikal satu per satu. Strategi ketiga adalah transisi dari strategi pemisahan dari kolom satuan ke kolom puluhan yang terdiri dari penghitungan kolom yang disingkat untuk hasil sementara di setiap kolom. Selain itu, ditemukan beberapa siswa melakukan kesalahan umum terkait miskonsepsi tentang algoritma dan masalah aritmatika. Implikasi dari temuan penelitian untuk proses pembelajaran dalam perhitungan nilai tempat dan algoritma dijelaskan secara rinci dalam artikel ini.
\end{abstract}

Kata kunci: pemikiran matematika siswa, perhitungan, algoritma, sekolah dasar

Copyright (c) 2021 Puri Pramudiani, Tatang Herman

$\triangle$ Corresponding author: Puri Pramudiani

Email Address: puri.pramudiani@uhamka.ac.id (Jl. Tanah Merdeka Kp. Rambutan Jakarta Timur)

Received 16 June 2021, Accepted 07 July 2021, Published 12 July 2021

\section{INTRODUCTION}

The aim of education is not only the ability to correctly and quickly run prior task and command but also the ability to think and make decisions (Isoda, M., \& Katagiri, 2012). To develop students' thinking, mathematics is known as a subject which can practice them. Mathematics as one of the subjects in school which plays an important role in preparing students, especially in developing thinking skills and solving complex problems (Herman, 2020). 
Mathematical thinking enables students' understanding towards the necessity of using knowledge and skills (Isoda, M., \& Katagiri, 2012). It can be investigated by using contexts which are familiar for students. Using realistic mathematical context will enable students to become inventor because mathematics is an essential part in daily life as it is a form of human activity (Pramudiani et al., 2016). The context itself should be meaningful for students' mind. Zulkardi \& Putri (2010) stated that the context is a key point for students in developing mathematics. Context can be developed from phenomenological exploration. It will enable students to make symbol or model of situation for progressive mathematization. Models are fundamentally used to raise a concrete situation of starting point for promoting formal mathematics (Gravemeijer, 1994). Furthermore, it is stated that the transformation from model of into model for is specified in the four level structures, i. e. situational level, referential level, general level, and formal level.

Concerning to the importance of cultivating students' mathematical thinking, in the present research, the researchers are interested to assess students' capability related to skills, knowledge, and development of students' mathematical thinking related to calculation and algorithm. Nelissen (1999) stated that knowledge is the result of activities perceived from learning. The contextual situation given to students related to addition and subtraction problem. It was administered to students subsequently from phenomenological exploration (using context) followed by formal mathematical problem (without context). This has purpose to assess how far the mathematical thinking of students related to the problem given. Besides that, the problems were developed through giving special problems in depth understanding and magical problems related to addition and subtraction. In this case, the students were expected to use their intuition to come to the idea of number sense. Hogarth (1992) identifies the three components that can promote students' intuition i. e. 1) creating awareness, 2) a framework for obtaining specific learning skills, and 3) practice.

In this study, it is focused on students' mathematical thinking in calculation numbers and algorithms. The reason of why we choose calculation numbers because according to National Research Council [NRC], 2001 (Anghileri in Purnomo et al., 2014) number is one of the most basic mathematical concepts in the primary school that has purpose in (1) resolving daily-life problems, (2) becoming the basis of all mathematics curriculum, and (3) promoting number sense. Algorithms are "recipes" for calculation with digits (TAL TEAM, van den Heuvel-Panhuizen, 2008). The example of algorithm for addition is as follows:

463

$\underline{382+}$

$845 \rightarrow 3+2=5 ; 6+8=14$, write down 4 , remember 1

Algorithms are used when operating with relatively large whole numbers and multi-digit decimal numbers that are difficult to calculate mentally in a fast and simple fashion. At any rate, this is the way it used to be, but nowadays, people can use a calculator in many of these cases. In the above example, however the numbers are too small to make it worthwhile using a calculator. Even using the addition algorithm may be excessive for such a simple problem. The general opinion is that students in grades 3 and 4 must be able 
to solve such problem without using an algorithm (TAL TEAM, van den Heuvel-Panhuizen, 2008). This can be done in various ways, one of which is column calculation.

463

$\underline{382+}$

700

140

$5+$

845

$$
\rightarrow 700 \rightarrow 840 \rightarrow 845
$$

Column calculation is characterized not so much by the vertical method of writing down the problem, but by the "splitting" strategy (using the positional values of numbers when calculating interim results), working from large to small, from left to right. This contrasts with algorithms, which operate with digits while working from small to large, from right to left (TAL TEAM, van den Heuvel-Panhuizen, 2008).

The addition algorithm can be seen as the latter abbreviation of column addition. According to TAL TEAM, (van den Heuvel-Panhuizen, 2008) there are three strategies in addition algorithm. The second strategy is the splitting strategy used from tens column to units column and the interim results are added vertically digit-by-digit. The third strategy is the transition from splitting strategy from units to tens column consists primarily of using abbreviated column calculation for the interim results in each column. This is where the transition takes place form calculating with the positional values of numbers $(5+140+700)$ to calculating with individual digits $(2+3=5 ; 6+8=14$; write down 4 remember $1 ; 1+4+3=8)$. When the term "column calculation" is used, it refers to the term "algorithm calculation" (the third strategies). In the case of addition, algorithm calculation can therefore be considered as a natural extension and closure of column calculation and mental arithmetic, the final step of an "three processes" of progressive schematization and automatization of arithmetic operations (TAL TEAM, van den Heuvel-Panhuizen, 2008). Column (mental) calculation and algorithm calculation are therefore related.

At the second half of the $20^{\text {th }}$ century, there was a change to the existing standard algorithms (TAL TEAM, van den Heuvel-Panhuizen, 2008). In subtraction, for example, the students were encouraged to work with groups of digits where required such as follows:

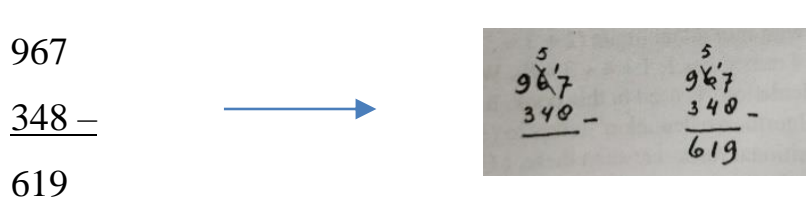

When $7-8$ is impossible, therefore usually in traditional algorithm the students are taught to borrow a ten from the neighboring column. However, sometimes students only can do the algorithm procedures without understanding what the meaning behind it. They just follow the teacher's instruction. This becomes dangerous when students only know the procedure without understanding the concept. The ability to use mathematical thinking is even more important than knowledge and skill, because it enables driving of the necessary knowledge and skill (Isoda, M., \& Katagiri, 2012). Therefore, this research has aim to assess the 
mathematical thinking of students in doing calculation and algorithm and also make a recommendation of the design activities and the context for the teaching and learning as well as suitable with the purpose of the aim of education to develop students' knowledge and skill through mathematical thinking.

\section{State of the Art}

As mentioned previously, students' mathematical thinking is very important as a key point to solve the problem related to mathematical problems. However, according to (Zulkardi, 2003), mostly 'local' mathematics textbooks contain primarily sets of rules and algorithms and they lack applications that are experientially real to the students. Furthermore, it is stated that in fact, the results of the tests showed that most students lacked comprehending of the basic skills that they should have studied in primary school and in daily life problems. The meaningful context can promote students' learning from informal level to preformal level consisting mathematical ideas (Pramudiani et al., 2011).

\section{Research Urgency}

This research is very important since mathematical thinking is a core of students in doing mathematical context. Mathematical thinking plays as a drive for students' understanding which underlies knowledge and skills (Isoda, M., \& Katagiri, 2012). When students only can do traditional algorithm procedure without understanding the mathematical concept, it becomes dangerous for them to solve mathematical problem related in daily live because mathematics is a human activity (Freudenthal in Pramudiani et al., 2011).

\section{METHOD}

To reach the goal of this research, the qualitative descriptive research was chosen using the procedures such in the following figure:

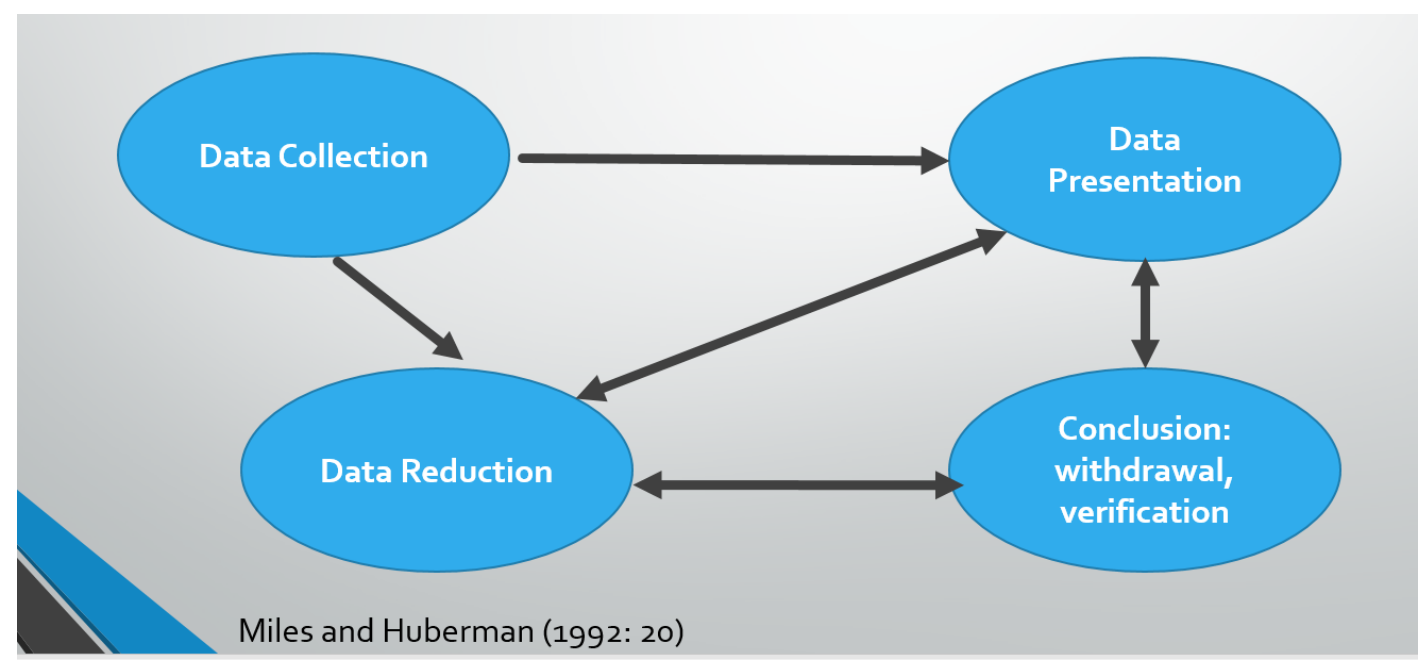

Picture 1. Scheme of Data Analysis Technique by Miles and Huberman (1992)

The data analysis technique involved data collection, data reduction, data presentation, and conclusion. Creswell \& Creswell (2018) stated that the characteristics of qualitative research, some of which are the natural setting, the meaning of the participants, and the theoretical views. Therefore, to reach the 
goal of this study, the information about students' mathematical thinking towards calculation algorithms were investigated elaborately through students' written work, observation, discussion, and interview, and then the result was analyzed by applying the conception of calculation algorithms.

\section{Participants}

Purposive sampling method were chosen to select the target of the research because in COVID-19 pandemic, most schools in Indonesia implemented learning from home policies to prevent the spread of corona viruses. Therefore, some students who were easily accessible by researchers become the research subjects. They were primary school students at grade 3 or 4 ( 9 or 10 years old) in Ciparay Bandung West Java. The characteristics of the students were intermediate level. The total numbers of these students were twelve students. However, there were only ten students who could be analyzed in detail because two of them still could not read text properly.

Afterwards, interview was organized to all ten students who were selected after analyzing data. The researchers chose them by considering their written works as some of them showed similar strategies, mathematical thinking, mistakes, and misconceptions.

\section{Calculation Questions}

Ten questions of calculation used in this research were developed from "Children Learn Mathematics" book (A Learning-Teaching Trajectory with Intermediate Attainment Targets for Calculation with Whole Numbers in Primary School) developed by TAL TEAM, Panhuizen, M.H. from Freudenthal Institute (FI) Utrecht University and National Institute for Curriculum Development (2008). All contents have been modified using Indonesian context included: addition and subtraction problem (both using context and without context), special problems in depth understanding and fun, and magical problems related to addition and subtraction problems. In addition to developing critical thinking and learning to believe the power of their own thinking, the students also need to be helped to find pleasure in mathematics (TAL TEAM, van den Heuvel-Panhuizen, 2008).

Addition and subtraction problems using Indonesian context allowed the researchers to figure out how students work with those contents using phenomenological exploration and doing progressive mathematization afterwards. Subsequently, the students were given special problems in depth understanding and magical problems related to addition and subtraction problems in order to evaluate how far they understand the calculation problems in fun ways. Concerning to validity of the instruments, the researchers discussed it to three experts in mathematics education. Improvement and suggestions were acquired.

\section{Procedures}

The study involved combining data through a written test and interviews. Therefore, the data consist of two types: written data and interview data. The test was given to 12 primary school students. They were primary school students at grade 3 or 4 ( 9 or 10 years old) in Ciparay Bandung West Java. Collecting data consisted of 3 phases. 
The first phase was held on $9^{\text {th }}$ December 2020. In the first phase, the students' initial knowledge towards calculation and algorithm were assessed. In this stage, they were asked to accomplish four questions. First question was about addition problem using context and second question was about addition problem without context. In the third question they were asked to solve subtraction problem using context and fourth question was about subtraction problem without context. In the first week, the researchers analyzed the students' written works and classified them into several strategies.

The second phase was held on $16^{\text {th }}$ December 2020. In the second phase, the researchers explored the students' mathematical thinking using broader problems. It was about inkblot problems (taken from (TAL TEAM, van den Heuvel-Panhuizen, 2008) and magical problems which has adjusted to Indonesian context. In this stage, the researchers were not only giving the written works but also the discussion class was raised after they finished their works.

After analyzing the students 'written works, on the third phase held on $17^{\text {th }}$ December 2020 , the researchers organized interview to acquire further information and justification related to students' work by asking them to explain their strategies and concepts used. To do this, the questionnaires were prepared beforehand to guide the researchers during interview. When interviewing, the health protocol and keep distancing were applied because when the research was conducted it was still on the COVID-19 pandemic situation. In this stage, the students described and gave more explanation about their answers, and perhaps their mathematical thinking could be observed.

\section{Data Analysis}

The results of students' written works were compiled. The students' written works were labelled sequentially from A1 to A12 in order to help the researchers in identifying their work during analysis. Afterwards, each question was analyzed elaborately. Establishing categories of students' strategies were conducted by three sequential stages. The first stage was to evaluate students' initial knowledge towards calculation and algorithm. In other words, we analyzed each students' work on addition and subtraction problems both using context and without context subsequently. The differences expression in how students understood the problems, they chose appropriate strategies (either using column calculation or algorithm including splitting strategies). The second stage was to dig up their mathematical thinking by applying special problems in depth understanding and fun, and magical problems related to addition and subtraction problems, that is, the teaching and learning process through discussion class was held in this stage. Then, the third stage was to gain students' mathematical thinking which consisted of expressing students' reasoning towards their work and explaining the strategies they used. In this stage, the researchers asked them whether they used their strategies from their own thinking or they just followed the instruction from teacher in their class.

Confirming students' understanding towards number calculation and algorithm, we made a tricky question by asking them whether can we switch the order of algorithm in column calculation. For example, when they solved the addition problem using number column calculation, they get used to do it from right to left (from units to tens). In this case, the researchers asked them that "Can we start the calculation from 
left to right (from tens to units)?". Some of them answered that "Yes, we can". After they declared that they could do it, they proofed it in that way. However, they made mistake when they combined tens and units, so that they got confused why the results were different. As well as to subtraction problem, when they stated that they could not subtract the above number with the bottom number because the above number was less than the above number, usually they "borrowed" 1 from the left number. However, some of them could not explain why they should do this. They just said that their teacher asked them to do so. Concerning to students' common mistake, the analysis was conducted by evaluating each question based on the contents of calculation. Since there were six problems, we all students' response were investigated towards problems one by one. Then, all students' mistakes were listed and categorized it based on their reason.

In determining types of students' strategies and their common mistakes, the researchers classified it based on literatures. Consultation to three experts in mathematics education was conducted and eventually approval was acquired.

In this study, belief could be depicted through dependability, transferability, credibility, and confirmability (Guba \& Lincoln in Aziz et al., 2017). Various students' reasoning in the interview questions and data collection procedures were explained. Interviews and all the activities held in this research were recorded and can be accessed in Youtube so that there was not any losing information. Theoretical purposive sampling and further description were held to confirm transferability (Aziz et al., 2017). Triangulation also was organized whereas the researchers used multiple methods of data collection such as students' written works, interview, investigating questions, and literature review. Finally, students' reasons for applying the strategies and confirming their difficulties and including students' categories were described further in the result and discussion.

\section{RESULTS AND DISCUSSION}

The results of the analysis showed important data considering students' strategies and common mistakes while solving the calculation problems. Therefore, the students 'strategies were classified into three categories namely: 1) splitting strategy from units to tens column and then the interim results are combined.; 2). splitting strategy used from tens column to unit column and the interim results are added vertically digit-by-digit, and 3) the transition from splitting strategy from units to tens column consists primarily of using abbreviated column calculation for the interim results in each column. Based on the focus of this research, all of which were elaborated by describing important data (students' written responses or interviews). Therefore, the three strategies of number calculation and algorithm in each problem were included as important discussion elaborately of several students' common work.

Before analyzing data in detail, the researchers labelled students from A1, A2, A3, A4, A5, A6, A7, A8, A9, A10, A11, and A12. However, two of them (A1 and A4) could not be analyzed further because they still could not read the text properly. Both of them were in grade 3 (9 years old). So, there were only ten students who were analyzed completely. 


\section{Students' Strategies in Addition Problem}

The first stage is assessing students' initial knowledge towards calculation using context. The problem was given to students in Bahasa Indonesia, while in this report the problem was translated into English version. Herewith the problem given to students:

Upin bought 65 candies, while Ipin bought 47 candies. If Upin and Ipin' candies are added up, what is the total number of candies?

From ten students, almost all of them could solve the problem correctly. Seven of them, namely A2, A6, A7, A9, A10, A11, A12 used column calculation with algorithm and described it in following ways:

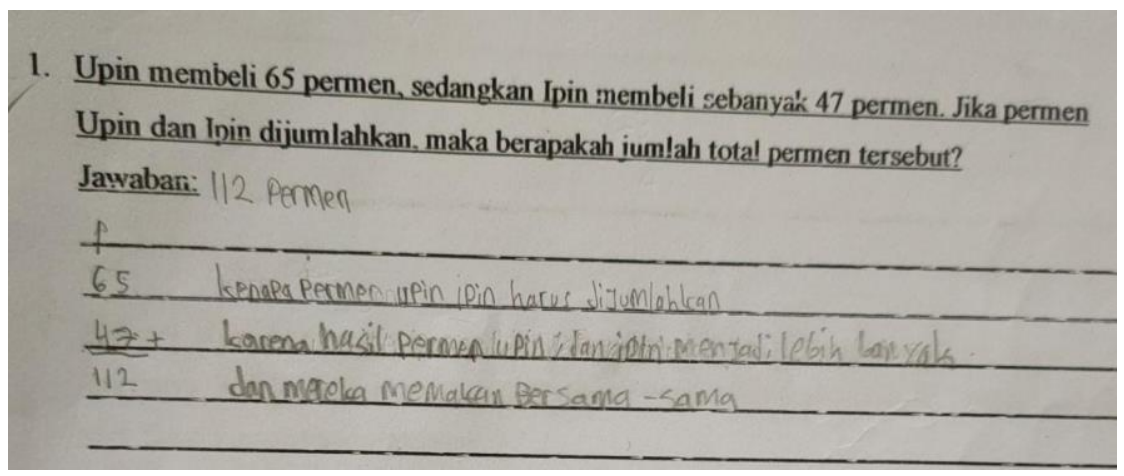

Picture 2. Students' Answer Using Column Calculation

When they did calculation, they used splitting strategies from units to tens. When they added units become more than 10, then they just wrote the interim number in column unit, and then added 1 which has meaning 10 to the column of tens. When the researchers asked them why they used that procedures, they answered that they knew it from their teacher or their parents. However, none of them used symbol or model to become a bridging from contextual situation to progressive mathematization. Although they did not make symbolization, all of them could give reasoning that why they solved using addition procedures, it was because when the candies of Upin and Ipin were added, then the total numbers become larger.

There was one student (A5) who used splitting strategy from tens to units and answered it correctly. However, he made mistake when he wrote number one hundred as 1000 . The strategy of A5 was in the following way:

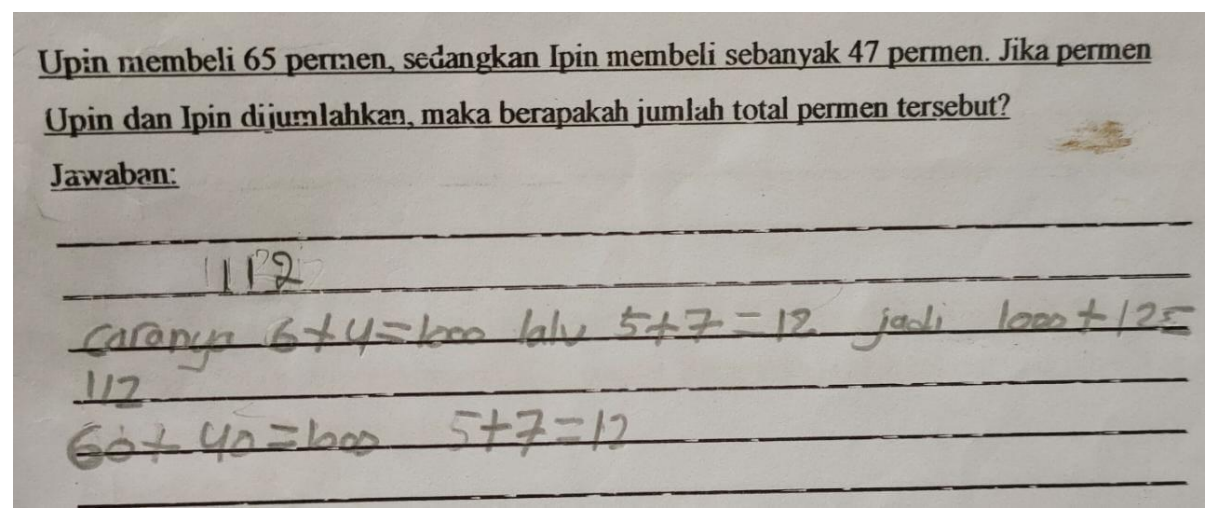

Picture 3. Student' Answer Using Splitting Strategy 
Besides that, there was one student (A8) who used column calculation but wrong answer, such in the following way:

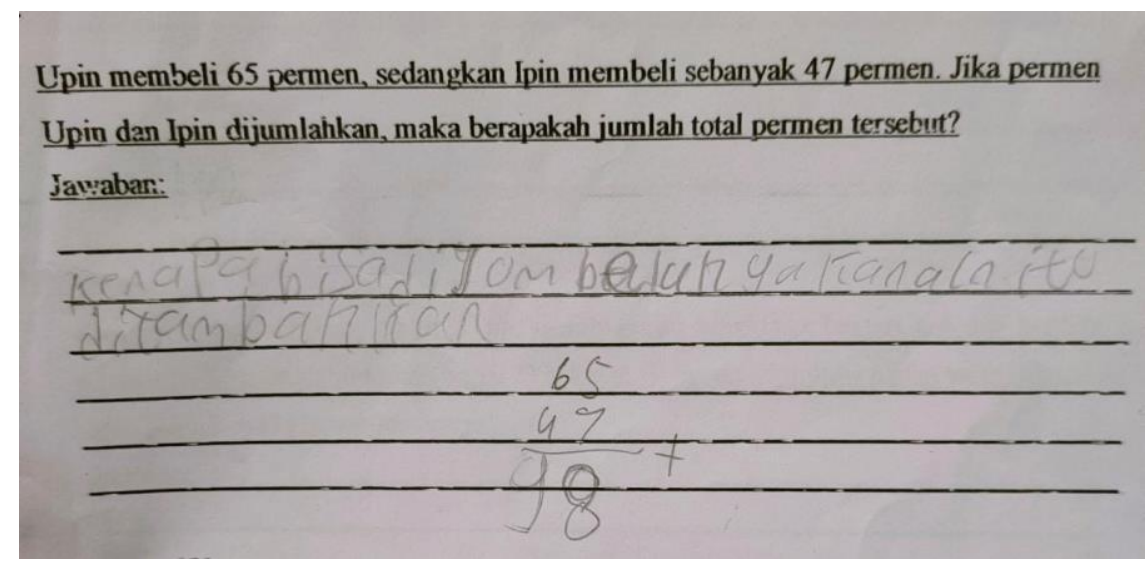

Picture 4. Student’ Answer Using Column Calculation with Common Mistake

When the researchers interviewed A8, he showed that he did not calculate numbers carefully. This mistake is common encountered in students because from the observation held by the researchers, most of students still count numbers manually (using fingers). There were only several students who could calculate mentally and used the concept of tens and units. Besides that, there was only 1 student (A3) who used unknown strategy and answered it incorrectly. However, he started up to use symbol to interpret the candies.

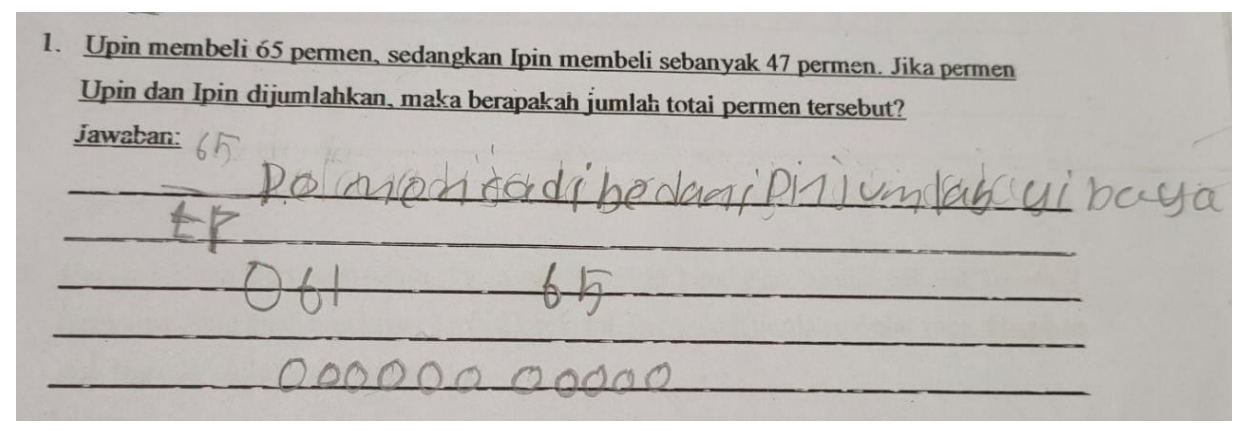

Picture 5. A3's answer

To interpret the students' strategy, the researchers asked his reason through interview. In this case, the researchers thought that he did not understand mathematical problem. Although he could read text rightfully, but when the researcher asked him to write numbers, he could not do it correctly. For example, when he was asked to write number 4 , he wrote in following ways:

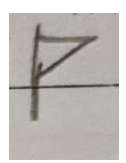

Picture 6. Symbol 4 Written by A3

From picture 5, we can see that A3's knowledge in formal mathematization was still lack. Instead of using mathematical symbol, he preferred to use model of candies (model of situation). 
The investigation about students' abilities in doing addition, the researchers gave similar problem without context by asking them to answer $463+382=\ldots$ From ten students, almost all of them could solve the problem correctly. Six of them, namely A2, A6, A7, A9, A10, A12 used column calculation with correct reason such in the following way:

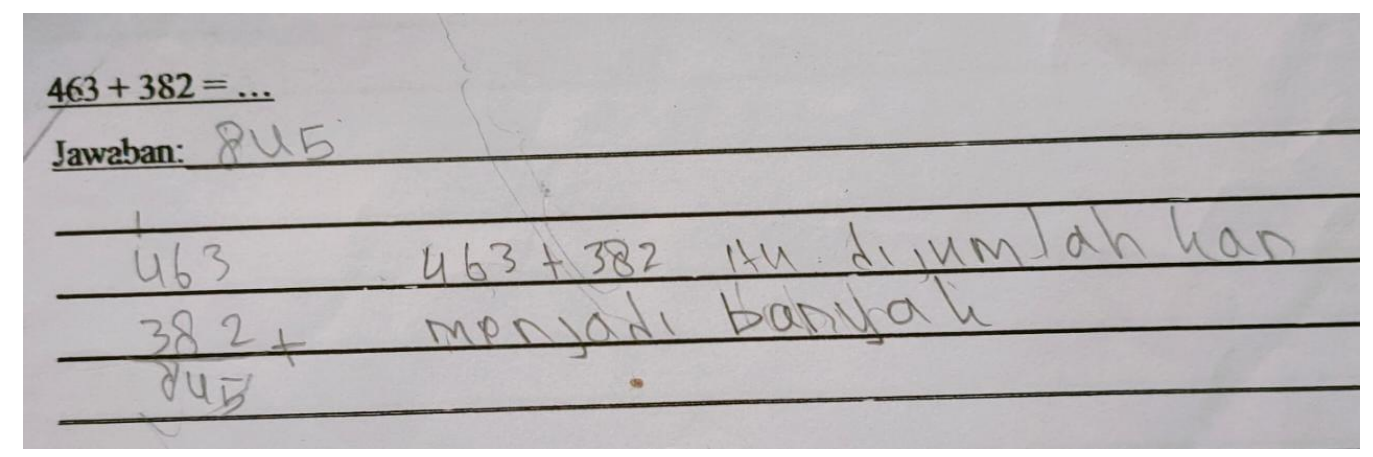

Picture 7. Students' Answer Using Column Calculation

There were one student (A5) who answered correctly without column calculation. When the researchers interviewed him, he did calculation mentally. Three students (A3, A8, and A11) answered incorrectly but they knew that when there was symbol (+) the result should become larger, but their results in calculation were wrong.

The next calculation was about subtraction. Herewith the problem given to students:

Ms. Ros bought 75 eggs. On her way, 18 eggs were cracked. The number of Ms. Ros's eggs that are still good ...

From ten students, there were six students who answered correctly with correctt reasoning, namely A2, A3, A6, A7, A8, and A12. They used column calculation with algorithm and described it in following ways:

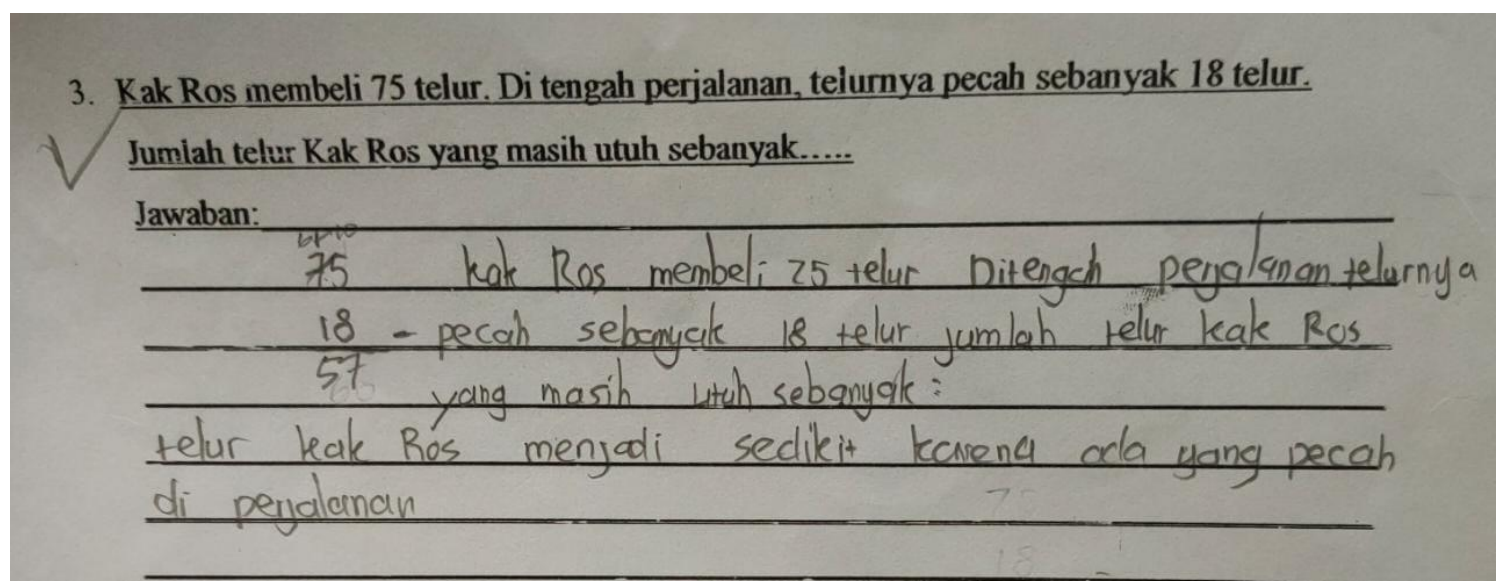

Picture 8. Students' Answer Using Column Calculation

From picture 8, we can see that when they did calculation, they used splitting strategies from units to tens. When they subtracted above number with below number whereas above number was less than below number, they borrowed 1 which means 10 from left and added it to the above number. When the researchers asked them why they used that procedures, they answered that they knew it from their teacher or their 
parents. However, none of them used symbol or model to become a bridging from contextual situation to progressive mathematization. Although they did not make symbolization, all of them could give reasoning that why they solved using subtraction procedures, it was because when the eggs of Ms. Ros were cracked along her way, then the total number become smaller.

The rest 4 students (A5, A9, A10, and A11) answered incorrectly, and their mistakes were commonly. They did calculation in wrong way such in the following way:

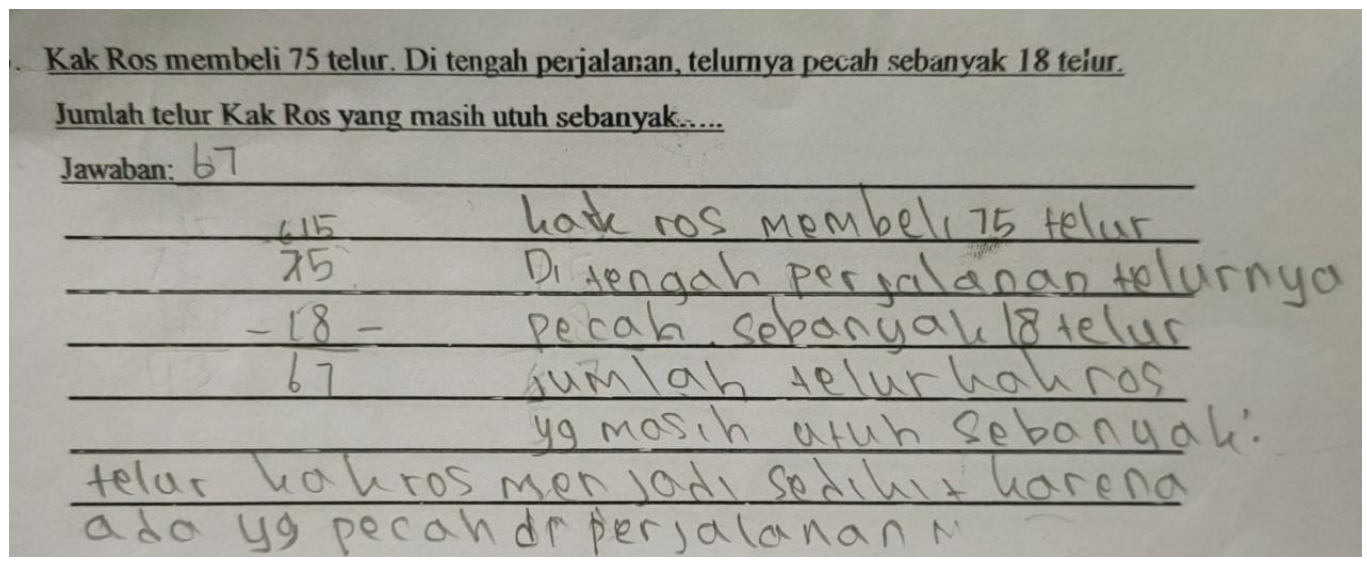

Picture 9. Students’ Answer Using Column Calculation with Common Mistake

From picture 9 we can see that the students had already used the column calculation and knew how they should do when the above number was less than the below number by borrowing ten from left column, but they did mistake when they subtracted tens column. They forgot that the number in ten columns above should be subtracted by 1 which means ten. Therefore, the result became wrong.

To investigate students' abilities in doing subtraction, the researchers gave similar problem without context by asking them to answer $967+348=\ldots$ From ten students, almost all of them could solve the problem correctly. Seven of them, namely A2, A3, A5, A6, A7, A10, A12 used column calculation with correct reasoning such in the following way:

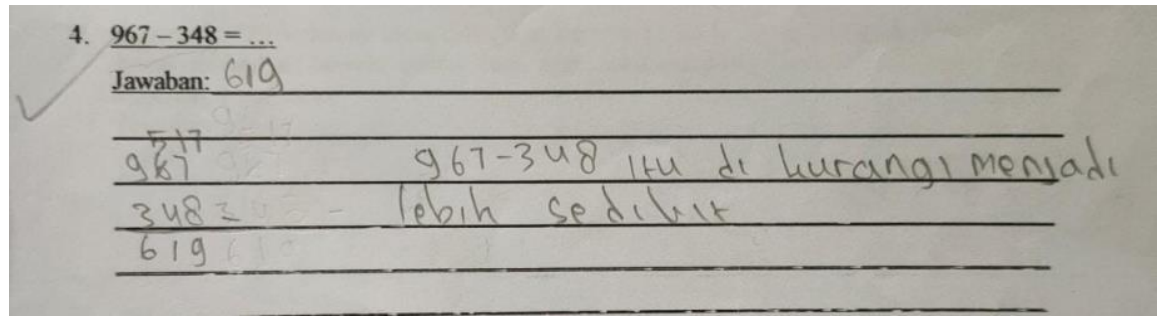

Picture 10. Students' Answer Using Column Calculation

The rest 3 students (A8, A9, and A11) answered incorrectly, and their mistakes were commonly that they calculated the number in wrong result.

\section{Special Problems in Depth Understanding}

The special problems that were discussed in this research aim at deepening insight into column calculation, and especially into algorithm calculation. However, because their puzzle-like they also function as part of recreational arithmetic and consequently help to stimulate the acquisition of mathematical attitude 
(TAL TEAM, van den Heuvel-Panhuizen, 2008). There were two types of problems given to students i. e. inkblot problems and magical problems. Both of them were taken from TAL TEAM, Panhuizen, M.H. book developed by Freudenthal Institute (FI) Utrecht University and National Institute for Curriculum Development (2001) and had been adjusted to Indonesian context. The problem is as follows:

\section{Inkblot Problem}

In inkblot problems, an inkblot covers a part of the number. As a result, the answer cannot be determined directly. However, it is possible to make the correct choice from several possible answers by using reasoning and calculating. Herewith the problem:

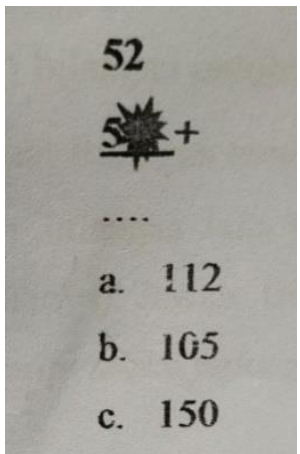

Picture 11. Inkblot Problem

From 10 students, there were 7 students (A2, A5, A7, A8, A10, A11, and A12) who can answer correctly. However, there was only 1 student (A2) who can give the reason using mathematical idea why he chose that answer such in the following way:

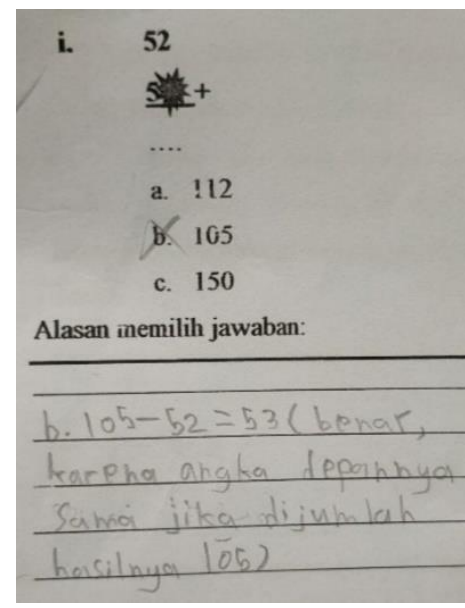

Picture 12. A2's answer in Inkblot Problem

From picture 12, we can see that he answered 105 because he paid attention to the left column numbers. He said that when the left column numbers were same, then he added it became 105 . Whereas the six students could answer correctly without giving the detail reasoning. When the researchers interviewed them, they said that they just estimated the numbers. However, three students (A3, A6, and A9) could not answer at all, and said that it was difficult for them because there was no information about the number covered by ink. 
From this problem, it can be concluded that the students had already possessed the basic of mathematical thinking. When the researchers asked them whether they had ever encountered the similar problem or not, all of them said that it was their first time to solve this type of problem. In fact, most of them could solve it correctly, event though some of them only estimated the numbers and without gave reasoning, but the researchers believed that when they get used to it, then their mathematical thinking will be developed.

\section{Magical Problem}

At the end of the section written test, the researchers conducted the mini teaching and learning activities by asking the students to play magical problem. The situation was set up like they really played magical problem. They were asked to follow the researchers' instruction such as follows:

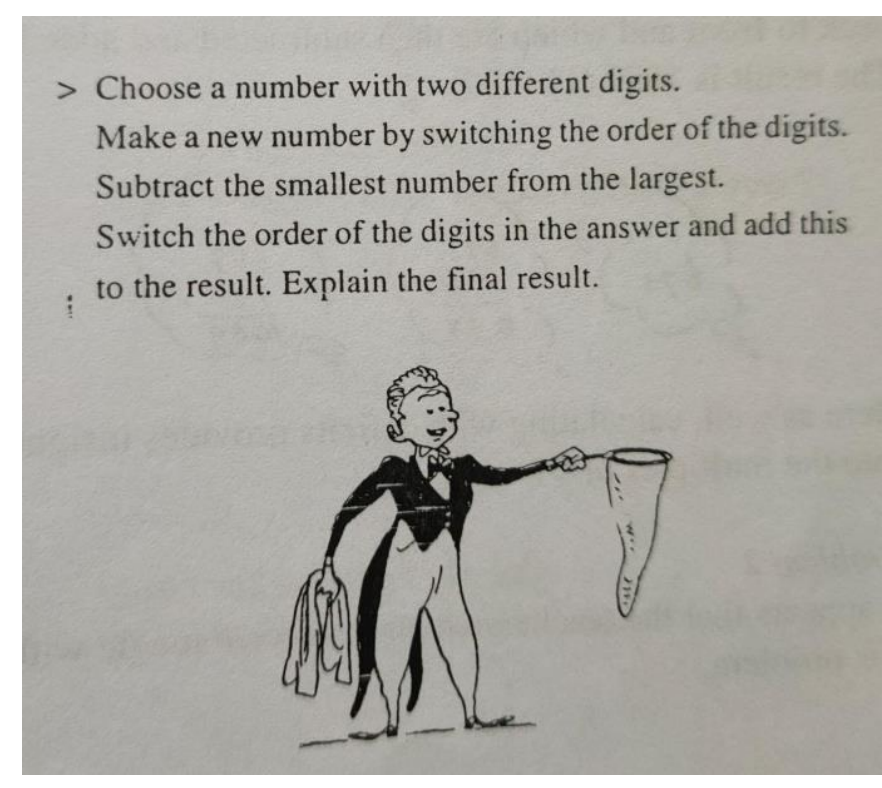

Picture 13. Magical Problem

Note: the problem was taken from TAL TEAM, Panhuizen, M.H. (2008) book developed by Freudenthal Institute (FI) Utrecht University and National Institute for Curriculum Development (2001) and had been adjusted to Indonesian Context.

In this activity, the students were asked to choose 1 number with two different digits. The number chose by each student should be different. After that, they were asked to make a new number by switching the order of the digits, then they have to subtract the smallest number from the largest. After that, they were asked to switch the order of the digits in the answer and added to the result of subtraction. Finally, they had to show their final result. Surprisingly, all the result was 99 even though they chose different numbers. When they were asked how could this happen, no one of them answers correctly. In fact, the result of the subtraction step is a multiple of 9 can be understood by calculating with deficits. If the students recognize that the total of the digits of the table of 9 is always 9 , when they are added together the final result 9 appears in both the units place and in the tens place. Therefore, the answer is always 99. Unfortunately, in this case the students' thinking had not yet reached that level but designing activities in this way enabled students to 
perform mathematical learning in fun way and they were very enthusiasm doing this. All the activities have been recorded and can be access in YouTube:

https://www.youtube.com/watch?v=wfyBbVUwq2A\&feature=youtu.be.

Column calculation consists of the standard procedures of addition, subtraction, multiplication, and division. However, in this research we focus only to the addition and subtraction including algorithm. The finding of this research suggests that the procedures implemented by students were closer to traditional algorithms using column calculation rather than mental arithmetic and estimation. The students learned the procedures of the vertical form of calculation through a gradual process of schematization and abbreviation. When they were asked how they knew this procedure, they said that they just followed the examples from teacher in their class or from their parents in their home. Because in this pandemic COVID-19, all students in Andir Ciparay Bandung studied from home, and of course the parents have an important role in educating students. However, the teacher still gave the learning material and assignment through WhatsApp group. Based on information from students, the mathematical problem given were taken from textbooks and it was rarely encountered problem with depth understanding like special problem given in this research (inkblot problem and magical problem). This suggests that we have to enrich contextual problems for applying the skills for students that function as a support point for developing their mathematical thinking.

\section{CONCLUSION}

According to previous sections, it showed that students used various strategies in solving the calculation problems. Students 'strategies were classified into three categories namely: 1) splitting strategy from units to tens column and then the interim results are combined.; 2) splitting strategy used from tens column to unit column and the interim results are added vertically digit-by-digit, and 3) the transition from splitting strategy from units to tens column consists primarily of using abbreviated column calculation for the interim results in each column. The common mistakes that students made in this research were caused by misunderstood about the concept of calculation and carelessness of arithmetical calculation. In general, the students' strategies to solve calculation problems were using algorithm as a basic procedure known from their teacher and parents. When they were asked special problems in depth understanding, there were only some students who could solve it. It means that in this research, some students were not get used to develop their mathematical thinking. They just followed the procedures given by the teacher or parents. However, when the problem developed in such a way like magical problem, they could solve it with great enthusiasm. It means, for further study, it will be necessary to develop the context and also teaching and learning process using mathematical ideas in order that students can develop their mathematical thinking.

\section{ACKNOWLEDGMENTS}

We are very grateful to twelve participants from primary school students grade 3 and 4 in Ciparay Bandung West Java and for their parents who were allowed their children to become the research subjects. Besides that, thank you to my supervisor who have given suggestion and worked well together, so this 
research was going well.

\section{REFERENCES}

Aziz, T. A., Pramudiani, P., \& Purnomo, Y. W. (2017). How Do College Students Solve Logarithm Questions? International Journal on Emerging Mathematics Education. https://doi.org/10.12928/ijeme.v1i1.5736

Creswell, J. W., \& Creswell, J. D. (2018). Research Design: Qualitative, Quantitative, and Mixed Methods Approaches. In Journal of Chemical Information and Modeling (5th ed., Vol. 53, Issue 9). Sage publications. https://doi.org/10.1088/1751-8113/44/8/085201

Gravemeijer, K. P. E. (1994). Developing Realistic Mathematics Education: Ontwikkelen Van Realistisch Reken/wiskundeonderwijs., 1994. CD-[Beta] Press, 13(3).

Herman, T. (2020). Menuju Indonesia Emas. UPI Press.

Hogarth, R. M. (1992). Educating Intuition. In University of Chicago Press. University of Chicago Press.

Isoda, M., \& Katagiri, S. (2012). Mathematical Thinking: How to Develop it in The Classroom ( ed. K. Stacey (ed.)). World Scientific Publishing Co.

Nelissen, J. M. . (1999). Thinking skills in realistic mathematics. Teaching and learning thinking skills. Swets \& Zeitlinger Publisher. https://core.ac.uk/download/pdf/93015312.pdf

Pramudiani, P., Purnomo, Y. W., \& Aziz, T. A. (2016). Identifying Pre-Service Primary School Teachers' Division Strategies. Jurnal Inovasi Pendidikan Dasar, 2(1), 9-18.

Pramudiani, P., Zulkardi, Hartono, Y., \& Amerom, B. A. Van. (2011). A Concrete Situation For Learning Decimals. Journal on Mathematics Education, 2(2). https://doi.org/10.22342/jme.2.2.750.215-230

Purnomo, Y. W., Kowiyah, Alyani, F., \& Assiti, S. S. (2014). Assessing number sense performance of Indonesian elementary school students. International Education Studies, 7(8), 74-84. https://doi.org/10.5539/ies.v7n8p74

van den Heuvel-Panhuizen, M. (2008). Children Learn Mathematics. In Children Learn Mathematics. BRILL. https://doi.org/10.1163/9789087903954

Zulkardi. (2003). DEVELOPING A LEARNING ENVIRONMENT ON REALISTIC MATHEMATICS EDUCATION FOR INDONESIAN STUDENT TEACHERS. Thesis University of Twente, Enschede. - With Refs. - With Summary in Ducth ISBN 9036518458 Subject.

Zulkardi, \& Putri, R. (2010). Mendesain sendiri soal kontekstual matematika. Prosiding KNM13 Semarang. 